\title{
MENINGKATKAN PERILAKU PROSOSIAL ANAK USIA 5 - 6 TAHUN MELALUI PERMAINAN TRADISIONAL BABINTINGAN
}

\author{
Dea Annisa ${ }^{1}$, Nurhayati Djamas ${ }^{1}$ \\ ${ }^{1}$ Program Studi Pendidikan Guru Pendidikan Anak Usia Dini, Fakultas Psikologi dan Pendidikan, \\ Universitas Al Azhar Indonesia, Jalan Sisingamangaraja Kebayoran baru, Jakarta Selatan 12110 \\ Penulis untuk Korespondensi/E-mail: ndjamas@uai.ac.id
}

\begin{abstract}
Abstrak - Salah satu aspek yang penting untuk distimulasi pada kehidupan anak adalah aspek perkembangan sosial. Secara harfiah, salah satu bentuk dari perilaku sosial yaitu perilaku prososial. Penelitian ini bertujuan untuk mengetahui apakah terdapat peningkatan perilaku prososial pada anak usia 5 - 6 tahun melalui permainan tradisional Babintingan di TK Bina Insan Mandiri.Penelitian ini merupakan penelitian tindakan kelas (PTK) yang menggunakan model Kemmis dan Mc Taggart yang dilakukan selama 2 siklus, dimana satu siklus terdiri dari 2 kali pertemuan. Subjek penelitian adalah 14 anak, yang terdiri dari 5 anak laki-laki dan 9 anak perempuan. Teknik pengumpulan data yang digunakan dalam penelitian ini adalah observasi perilaku prososial anak, aktivitas guru dan anak serta dokumentasi. Teknik analisis data pada penelitian ini terdiri dari tiga 3 tahapan yaitu reduksi data, mendeskripsikan data dan penyimpulan. Berdasarkan hasil penelitian diketahui bahwa terdapat peningkatan pada perilaku prososial anak usia 5 - 6 tahun melalui permainan tradisional Babintingan. Hal ini diketahui dari rata-rata anak yang mendapatkan skor berkembang sesuai harapan (BSH) pada indikator empati mendengarkan orang lain mengalami peningkatan sebesar $64 \%$, menerima sudut pandang orang lain mengalami peningkatan sebesar $61 \%$ dan peka terhadap orang lain mengalami peningkatan sebesar 64\%. Pada indikator kepedulian melisankan dukungan mengalami peningkatan sebesar $68 \%$ dan memberikan perlindungan fisik mengalami peningkatan sebesar $64 \%$. Pada indikator kerja sama bergiliran dalam beregiatan mengalami peningkatan sebesar $64 \%$, memenuhi permintaan mengalami peningkatan sebesar $57 \%$ dan mengoordinasikan segala tindakan mengalami peningkatan sebesar $82 \%$.
\end{abstract}

Kata Kunci: Perilaku Prososial, Permainan Tradisional Babintingan, Anak Usia 5 - 6 Tahun

Abstract - One aspect that is important to stimulate the lives of children is an aspect of social development. One form of social behavior is prosocial behavior. This study aims to determine whether there is an increase in prosocial behavior in children aged 5-6 years through the traditional play method Babintingan in TK Bina Insan Mandiri. This research is a classroom action research $(C A R)$ that uses the Kemmis and Mc Taggart models conducted for 2 cycles, where one cycle consists of 2 meetings. The research subjects were 14 children, consisting of 5 boys and 9 girls. Data collection techniques used in this study were observation of child prosocial behavior, teacher and child activities and documentation. Data analysis techniques in this study consisted of three stages, namely data reduction, describing data and conclusions. Based on the results of the study note that there is an increase in prosocial behavior of children aged 5-6 years through the traditional game method Babintingan. It is known from the average of children who get a score developing according to expectations (BSH) on the empathy indicator of listening to others has increased by 64\%, receiving the viewpoint of others has increased by $61 \%$ and sensitive to others has increased by $64 \%$. Concerning the indicator of expressing support, it has increased by $68 \%$ and provides physical protection has increased by $64 \%$. Indicators of cooperation in rotating activities increased by $64 \%$, meeting demand increased by $57 \%$ and coordinating all actions increased by $82 \%$.

Keywords: Prosocial Behavior, Babintingan Traditional Game, Children 5-6 Years 


\section{PENDAHULUAN}

$\mathrm{S}$ alah satu potensi yang sangat penting untuk distimulasi adalah aspek perkembangan sosial emosional. Aspek tersebut merupakan penghubung aspek-aspek lainnya dalam perkembangan seseorang. Seorang anak akan mendapat banyak pengalaman untuk membangun aspek perkembangan sosial emosionalnya melalui interaksi dengan lingkungan tempat mereka berada secara utuh.

Perilaku sosial merupakan suatu perilaku yang dapat terjadi pada siapa saja, mulai dari anakanak hingga dewasa sebagai makhluk sosial dan sebagai bagian dari suatu masyarakat. Secara harfiah, perilaku sosial terbagi menjadi 2 bentuk perilaku, yaitu perilaku prososial dan perilaku antisosial. Menurut Papalia, et al (2009) perilaku prososial (prosocial behavior) adalah segala perilaku sukarela yang ditujukan untuk membantu orang lain. Demikian juga Bar-Tal (dalam Desmita, 2009) mendefinisikan perilaku prososial sebagai perilaku yang dilakukan secara sukarela, menguntungkan orang lain tanpa antisipasi, reward eksternal, dan perilaku tersebut dilakukan tidak untuk dirinya sendiri, meliputi helping/ aiding, sharing, dan donating. Pentingnya perilaku prososial dalam kehidupan anak membawa dampak positif bagi pengembangan diri serta seluruh aspek dalam kehidupannya.

Perilaku prososial yang dapat dikembangkan oleh anak antara lain yaitu perilaku empati, kepedulian dan kerja sama. Empati merupakan kunci untuk memahami perasaan orang lain sehingga anak mampu menunjukkan sikap toleransinya, memberikan kasih sayang, memahami kebutuhan temannya, dan mau menolong teman yang sedang mengalami kesulitan. Anak yang berempati akan mampu mengendalikan emosinya dengan memberi dan menerima maaf serta mau bermain bersama dan saling berbagi dengan temannya. Anak yang tidak terlatih bersikap empati sejak usia dini kelak akan tumbuh menjadi pribadi yang tidak peka pada lingkungan terdekatnya, maupun sekitarnya. Anak yang tidak meniliki empati juga akan menjadi pribadi yang spontan menolong dan membantu masalah orang lain.

Kepedulian adalah perilaku seseorang yang bertanggung jawab atas kesulitan yang dihadapioleh orang lain dan terdorong untuk melakukan sesuatu untuk mengatasinya. Memiliki jiwa peduli sangat penting untuk diajarkan kepada anak usia dini. Selain memberi pengetahuan bahwa manusia adalah mahluk sosial yang selalu membutuhkan orang lain dalam kehidupannya, memiliki kepedulian juga memiliki manfaat agar anak lebih mudah bersosialisasi dan lebih dihargai oleh orang lain. Anak yang tidak memiliki kemampuan peduli akan selalu bersifat egosentris sampai kelak ia dewasa.

Anak usia 5 - 6 tahun juga mulai memiliki kesanggupan beradaptasi dari yang sebelumnya berfokus pada diri sendiri menjadi memperhatikan orang lain. Anak dapat berminat terhadap kegiatan-kegiatan teman sebayanya, dan bertambah kuat keinginannya untuk diterima menjadi anggota kelompok, dan merasa tidak senang apabila tidak diterima dalam kelompoknya. Situasi ini sering dimaknai oleh guru dengan memanfaatkan pembelajaran yang bersifat kelompok atau kerja sama. Kemampuan bekerja sama penting untuk dilatihkan sejak dini, karena pada proses bekerja sama, anak dapat mengembangkan kemampuan sosial emosional seperti bagaimana anak bisa berbagi, tanggung jawab, saling membantu, dan berinteraksi dalam menyelesaikan tugas bersama dengan kelompoknya.

Rendahnya perilaku prososial menurut McGrath (dalam Sugiono, 2014) dikarenakan orang tua lebih mengutamakan nilai akademik daripada pengembangan perilaku prososial. Hal tersebut dapat dimaklumi karena orang tua sebagai bagian dari masyarakat telah dikondisikan untuk meyakini bahwa keberhasilan akademis merupakan kunci bagi keberhasilan anak-anak dalam hidup. Keyakinan umum yang berkembang dalam masyarakat adalah bahwa jika anak-anak mendapatkan nilai A, masuk ke perguruan tinggi yang baik, meraih gelar yang baik, mendapatkan pekerjaan yang baik dengan gaji yang bagus maka keberhasilan dan kebahagiaan anak akan terjamin hidupnya. Pada perkembangannya justru ternyata banyak anak dengan nilai akademik yang tinggi ternyata tidak selalu berhasil dalam kehidupannya, baik itu ditempatnya bekerja maupun dalam lingkungan masyarakat. 
Berdasarkan Peraturan Menteri Pendidikan dan Kebudayaan Republik Indonesia No. 137 Tahun 2014 tentang Standar Pendidikan Anak Usia Dini (STTPA) bahwa aspek perkembangan sosial emosional pada lingkup perkembangan perilaku prososial pada anak usia $5-6$ tahun terdiri dari: 1) Bermain dengan teman sebaya;

2) Mengetahui perasaan temannya dan meresponnya secara wajar; 3) Berbagi dengan orang lain; 4) Menghargai hak atau pendapat atau karya orang lain; 5) Menggunakan cara yang diterima secara sosial dalam menyelesaikan masalah (menggunakan fikiran untuk menyelesaikan masalah); 6) Bersikap kooperatif dengan teman; 7) Menunjukkan sikap toleran; 8) Mengekspresikan emosi yang sesuai dengan kondisi yang ada (senang-sedihantusias-dan sebagainya); dan 9) Mengenal tata krama dan sopan santun sesuai dengan nilai sosial budaya setempat.

Untuk mengembangkan perilaku prososial tersebut dibutuhkan suatu metode yang tepat dan melihat berbagai aspek yang dapat mendukung anak. Salah satu metode yang dapat dilakukan yaitu kembali pada prinsip pembelajaran anak usia dini melalui sarana bermain. Belajar melalui bermain dapat mengasah dan meningkatkan kecerdasan yang dimiliki anak. Pengalaman anak lewat aktivitas bermain dapat memberikan dasar yang kuat bagi pencapaian macam-macam keterampilan yang sangat diperlukan bagi pemecahan masalah dalam kehidupan dikemudian hari. Anak yang banyak menggunakan waktu untuk bermain cenderung lebih dapat menyelesaikan masalah dikehidupan selanjutnya.

Metode bermain penting untuk diterapkan di taman kanak-kanak karena melalui bermain anak akan belajar berinteraksi dengan temannya, belajar bekerjasama, berbagi, dan bersikap toleransi. Hal ini didukung dengan hasil penelitian terdahulu oleh Astuti (2012) yang menyatakan bahwa metode bermain dianggap penting karena dengan bermain anak akan belajar berkomunikasi, dan berinteraksi dengan orang lain.

Salah satu permainan yang dapat dikembangkan adalah permainan tradisional. Permainan tradisional dilihat dari segi kebudayaan merupakan kebudayaan asli yang mendukung budaya nasional dan adat tradisi bangsa yang ikut memperkaya unsur kebudayaan dan kepribadian bangsa Indonesia. Pada awalnya permainan tradisional dimainkan dengan peraturan yang sederhana lambat laun permainan ini berkembang menjurus kepada permainan yang dipertandingkan atau diperlombakan. Lebih lanjut lagi beberapa macam bentuk permainan tradisional dimasukan sebagai pokok bahasan yang harus disampaikan dan dipraktekkan (Kusmaedi, 2010).

Bentuk permainan tradisional sangat sederhana dalam arti tidak begitu sulit dicari dan mudah dimainkan karena bisa disesuaikan dengan kondisi yang ada. Adapun unsur-unsur yang berpengaruh positif terhadap para pelakunya antara lain terhadap ketangkasan, kecepatan, kelincahan, kejujuran, kelenturan dan kerjasama. Selajutnya diharapkan dapat membina kesegaran jasmani dan rohani bagi para pelakunya.

Berdasarkan pengamatan yang peneliti lakukan pada tanggal 25 Maret 2019 pada anak usia 5 6 tahun di Kelompok B1 TK Bina Insan Mandiri, terdapat 12 dari 14 anak yang mengalami perilaku prososial rendah. Terdapat 6 anak yang belum terbiasa berempati terhadap apa yang dilakukan teman- temannya, seperti tidak melakukan apapun ketika temannya merasa sedih atau kesulitan, 5 anak yang belum memiliki kepedulian yang tinggi, seperti mengejek temannya ketika temannya dalam kesulitan dan 3 anak yang tidak mau bekerjasama dengan temannya ketika mengerjakan suatu kegiatan yang bersifat kelompok, seperti tidak mau meminjamkan barang-barang miliknya kepada temannya.

Berdasarkan pengamatan pula, peneliti melihat banyak faktor yang menjadi penyebab rendahnya perilaku prososial pada anak usia 5 - 6 tahun di TK Bina Insan Mandiri karena disebabkan guru kurang menerapkan metode pembelajaran yang menyenangkan kepada anak. Dalam melakukan kegiatan pembelajaran, guru lebih sering menggunakan metode pembelajaran tanya jawab, ceramah dalam bentuk klasikal, dan penugasan menggunakan lembar kerja dan buku paket yang telah disediakan di sekolah. Berdasarkan wawancara yang dilakukan pada hari yang sama, guru menyatakan bahwa dalam meningkatkan perilaku prososial, guru hanya menilai dari aktivitas bermain yang dilakukan anak di 
luar kegiatan belajar sepeti bermain sebelum memulai pembelajaran, bermain saat istirahat, dan bermain setelah pulang sekolah sebelum dijemput oleh orang tua atau wali anak.

Berdasarkan kondisi tersebut melalui diskusi dan refleksi dengan guru, disepakati solusi tindakan untuk memecahkan masalah tersebut yaitu dengan melakukan sebuah permainan tradisional yaitu Babintingan. Babintingan adalah sebuah permainan tradisional yang berasal dari Kalimantan Selatan, tepatnya di Kecamatan Simpur, Kabupaten Hulu Sungai. Babintingan berasal dari kata binting atau benteng, dinamakan seperti itu karena permainan ini menggunakan dua buah tiang seperti sebuah benteng pertahanan yang dimiliki oleh pemainnya.

Berdasarkan penelitian yang akan dilakukan, peneliti menggabungkan nilai-nilai dalam permainan tradisional Babintingan dengan 3 aspek dalam perilaku prososial, antara lain:

\section{Empati}

Perilaku empati yang muncul dalam permainan tradisional Babintingan yaitu ketika salah satu anggota kelompok tertawan, maka anak harus menjemput temannya kembali ke kelompok agar bisa bermain kembali.

2. Kepedulian

Perilaku kepeduliaan yang terdapat dalam permainan tradisional Babintingan terlihat ketika salah satu anggota kelompok merasa terkepung oleh lawan, anggota lain harus memiliki rasa kepedulian untuk membantu mengecohkan lawan tersebut.

3. Kerja sama

Perilaku kerja sama yang didaptkan melalui permainan tradisional ialah inti dari permainan di mana satu kelompok pemain bekerja sama untuk dapat menawan pemain lawan sebanyak-banyaknya dan merebut bentengnya.

Pada permainan tradisional Babintingan terdapat beberapa cara dan aturan dalam bermain, antara lain:

1. Permainan Babintingan biasanya dimainkan oleh 3-5 anak per kelompok

2. Setiap kelompok mempunyai satu tiang benteng.

3. Setiap kelompok berusaha mempertahankan bentengnya sendiri dan merebut benteng lawan dengan cara menyentuh pemain lawan. Pemain yang tersentuh disebut "dapat" atau tertawan.

4. Kelompok yang pemainnya tertawan akan mencoba ma-ambili atau menjemput temannya dengan berusaha ke benteng lawan dan menyentuhnya.

5. Apabila yang tertawan berhasil disentuh, dia dapat berusaha kembali ke bentengnya. Namun jika pemain yang ingin menjemput temannya malah tersentuh, itu adalah kerugian besar karena anggota kelompok tertawan yang tinggal dibenteng akan semakin sedikit.

6. Akhirnya bisa jadi hanya satu pemain yang tertinggal di benteng. Saat itu pemain lawan bisa mengepung benteng dan berusaha menyentuhnya. Apabila sudah tersentuh, kelompok pengepung berhasil menang dan diakhiri dengan kata "binting".

7. Keadaan juga bisa berbalik ketika seorang pemain yang tertinggal di benteng bisa menyentuh salah seorang pengepung atau "dapat". Semua pemain pengepung akan tertawan dan kemenangan berada di pihak yang terkepung.

8. Inti permainan ini adalah berupaya menawan pemain lawan sebanyakbanyaknya dan merebut bentengnya atau diistilahkan dengan mambinting (Tim PlayPlus Indonesia, 2016).

Selain itu, dalam permainan tradisional Babintingan terdapat tiga posisi dan peran yang ada dalam permainan, antara lain:

1. Penyerang, berperan sebagai anggota yang tugasnya menyentuh anggota tim lawan sebanyak-banyaknya. Biasanya penyerang adalah anggota yang kemampuan berlarinya cepat, karena dapat mengejar atau mengecoh tim lawan untuk dijadikan tawanan.

2. Penjaga, berperan sebagai anggota bertahan yang tugasnya ialah menjaga benteng tim dari serangan lawan.

3. Mata-mata, berperan sebagai anggota yang tugasnya menyerang benteng lawan secara sembunyi-sembunyi. Mata- mata biasanya mengendap-endap untuk dapat menyerang benteng lawan tanpa diketahui.

Untuk menambah pengetahuan anak mengenai materi permainan tradisional, peneliti menggunakan video animasi sebagai media 
untuk membantu anak memahami materi permainan dengan cara menonton bersama sebelum melakukan permainan.

\section{METODE PENELITIAN}

Sesuai dengan tujuan penelitian ini yaitu untuk meningkatkan perilaku prososial anak usia 5-6 tahun melalui permainan tradisional Babintingan, maka metode penelitian yang akan digunakan adalah Penelitian Tindakan Kelas (PTK). Penelitian tindakan kelas ini dilaksanakan di TK Bina Insan Mandiri yang terletak di Jl. Meruya Ilir Raya Blok A, RT. 1/RW. 1, Srengseng, Kecamatan Kembangan, Kota Jakarta Barat. Alasan peneliti memilih TK Bina Insan Mandiri, karena peneliti mengamati bahwa terdapat beberapa anak yang mengalami perilaku prososial rendah, antara lain terdapat anak yang belum terbiasa berempati terhadap apa yang dilakukan teman-temannya, seperti tidak melakukan apapun ketika temannya merasa sedih atau kesulitan, anak yang belum memiliki kepedulian yang tinggi, seperti mengejek temannya ketika temannya dalam kesulitan dan anak yang tidak mau bekerjasama dengan temannya ketika mengerjakan suatu kegiatan yang bersifat kelompok, seperti tidak mau meminjamkan barang-barang miliknya kepada temannya. Selain itu jarangnya penerapan metode bermain di dalam kelas.

Penelitian ini dilakukan selama dua siklus di mana setiap siklus terdapat dua kali pertemuan. Sehingga dapat dikatakan penelitian ini dilakukan sebanyak empat kali sampai dengan siklus ke dua. Subjek dalam penelitian ini adalah anak Kelompok B1 yang berusia 5-6 tahun di TK Bina Insan Mandiri Tahun Ajaran 2019 - 2020 berjumlah 14 anak yang terdiri dari 5 anak laki-laki dan 9 anak perempuan.

Rancangan penelitian yang akan dilakukan dalam penelitian tindakan kelas ini adalah berbentuk siklus, setiap siklus terdiri dari dua pertemuan. Rancangan penelitian yang digunakan mengacu pada model yang dikembangkan oleh Kemmis dan Mc Taggart yaitu model spiral, yang dalam pelaksanaanya merupakan proses pengkajian berdaur melalui empat tahap kegiatan yaitu perencanaan,

pelaksanaan, observasi, dan reflektif. Berdasarkan uraian desain penelitian di atas, berikut adalah langkah- langkah yang dilakukan dalam penelitian ini sebagai berikut:

\section{Perencanaan Tindakan}

a. Membuat desain pembelajaran yang memuat Rencana Pelaksanaan Pembelajaran Harian (RPPH), lembar observasi instrumen perilaku prososial anak, lembar observasi aktivitas guru dan anak, serta lembar penilaian dalam pembelajaran yang sudah di setujui.

b. Mempersiapkan sarana dan prasarana untuk kegiatan permainan tradisional Babintingan. Adapun sarana dan prasarana yang diperlukan dalam kegiatan permainan tradisional adalah sebagai berikut:

1) Video animasi untuk menjelaskan tata cara bermain permainan tradisional Babintingan,

2) Lapangan luas, dua buah tiang jaring bulutangkis dalam kegiatan permainan. Permainan tradisional Babintingan akan dilakukan pada kegiatan pembuka dalam waktu \pm 30 menit. Adapun penjelasan waktu pada siklus 1 adalah sebagai berikut:

a) Guru memutar video tata cara bermain permainan tradisional Babintingan selama \pm 5 menit

b) Guru membagi anak menjadi dua tim selama \pm 5 menit

c) Anak melakukan kegiatan permainan tradisional Babintingan \pm 15 menit

d) Guru melakukan evaluasi atau recalling ( \pm 10 menit)

3) Adapun cara permainan tradisional Babintingan ini adalah sebagai berikut:

a) Guru membagi anak menjadi dua kelompok yang terdiri dari tujuh anak.

b) Setiap kelompok harus berusaha menawan pemain lawan sebanyakbanyaknya dan memegang benteng lawan serta harus mengikuti peraturan yang telah diberikan sebelumnya.

4) Sticker untuk memotivasi anak dalam melakukan permainan

5) Melakukan diskusi dan memberikan arahan agar praktisi dalam melaksanakan perannya sesuai dengan rencana. 
2. Tahap Pelaksanaan Tindakan

Pada tahap pelaksanaan tindakan, peran peneliti adalah:

a. Memberikan tindakan sesuai dengan tahap perencanaan yang telah disusun

b. Bekerja sama dengan guru kelas dan teman sejawat dalam melaksanakan tindakan penelitian yang telah direncanakan. Adapun kerja sama yang dilakukan dengan guru kelas adalah dalam mengobservasi aktivitas anak dan peneliti. Sedangkan, kerja sama yang dilakukan dengan teman sejawat adalah dalam mengobservasi pelaksanaan dan mendokumentasikan jalannya penelitan.

\section{Tahap Observasi}

Observasi ini dilakukan dalam setiap pertemuan, di mana kegiatan dilakukan peneliti dalam tahap observasi ini adalah:

a. Memperhatikan anak selama permainan berlangsung dan memberikan bantuan pada anak yang mengalami kesulitan dalam kegiatan bermain.

b. Memperhatikan dan mengamati anak dengan mencatat kejadian yang terjadi dalam permainan tersebut serta mencatat perilaku prososial anak.

c. Pengamatan yang dilakukan pada siklus I sangat berpengaruh pada perencanaan pembelajaran yang akan dilakukan pada siklus selanjutnya.

\section{Tahap Refleksi}

Berdasarkan hasil data observasi yang sudah didapat, kemudian dilakukannya analisis dengan mendiskusikannya bersama pihak guru kelas. Hal ini dilakukan untuk mengetahui apakah melalui permainan tradisional Babintingan dapat meningkatkan perilaku prososial pada anak usia $5-6$ tahun di TK Bina Insan Mandiri. Refleksi pada siklus I akan dijadikan acuan perencanaan tindakan pada siklus II. Melalui data ini, guru dan peneliti dapat merefleksi diri sekiranya hal apa saja yang masih kurang atau memerlukan perbaikan dalam permainan pada siklus I, sehingga guru dan peneliti dapat melakukan perbaikan untuk siklus selanjutnya.

Kriteria ketuntasan dan keberhasilan pada penelitian ini apabila $75 \%$ anak sudah berperilaku empati, peduli dan kerja sama atau dapat dikatakan bahwa masing-masing indikator anak mendapatkan skor 3 yaitu berkembang sesuai harapan (BSH).

Teknik pengumpulan data yang digunakan dalam penelitian ini yaitu observasi dan dokumentasi. Analisis data dalam penelitian ini yaitu analisis kualitatif. Teknik analisis data kualitatif ini mengacu pada metode analisis dari Miles dan Huberman (Sugiyono, 2009). Metode ini terdiri atas tiga komponen yaitu reduksi data, penyajiian data dan penarikan kesimpulan.

Kriteria pada penelitian ini yaitu anak diharapkan mampu meningkatkan perilaku prososial, setelah melakukan permainan tradisional Babintingan. Berdasarkan yang telah dijelaskan oleh Tampubolon (dalam) bahwa penelitian ini dikatakan berhasil apabila $75 \%$ dari jumlah anak yaitu 14 anak mampu mencapai skor 3 yaitu berkembang sesuai harapan.

\section{HASIL DAN PEMBAHASAN}

1. Siklus I

a. Perencanaan

Pada tahap perencanaan siklus I, peneliti membuat persiapan pembelajaran. Peneliti mendiskusikan setting pembelajaran yang akan peneliti lakukan dan mempersiapkan Rencana Pelaksanaan Pembelajaran Harian (RPPH) bersama dengan guru kelas. Selanjutnya, peneliti mempersiapkan media yang akan digunakan dalam menjelaskan tata cara bermain, posisi dan peran yang terdapatdalam permainan tradisional Babintingan, yaitu berupa video. Kemudian menyiapkan lembar observasi peningkatan perilaku prososial anak, lembar observasi aktivitas guru dan anak, dan Gambar 4.1 Diagram Perilaku Prososial pada Aspek Empati Anak Usia 5 - 6 Tahun di TK Bina Insan Mandiri pada Siklus Imenyiapkan reward yang akan diberikan untuk memotivasi anak berupa sticker serta kamera DSLR untuk mendokumentasikan kegiatan pembelajaran.

\section{b. Pelaksanaan Tindakan}

Pelaksanaan tindakan siklus I dilaksanakan selama dua kali pertemuan yaitu pertemuan pertama pada hari Selasa, 12 November 2019 dan pertemuan kedua pada hari Kamis, 14 November 2019. Kegiatan 
penelitian hanya dilakukan pada kegiatan pembuka setiap kegiatan pembelajaran, yaitu pada kegiatan motorik yang biasa dilakukan dikelas setelah berdoa.

c. Observasi

Hasil pengamatan perilaku prososial anak pada aspek kepedulian siklus I diuraikan melalui tabel.

d. Refleksi

Hasil pengamatan penelitian pada siklus I menunjukkan bahwa indikator keberhasilan belum tercapai. Berdasarkan hasil pengamatan dan diskusi oleh peneliti, guru dan teman sejawat, diperoleh hal-hal yang menjadi penghambat pada siklus I, antara lain:

1) Observasi Aktivitas Guru. Berdasarkan observasi yang dilakukan guru kepada peneliti dapat diketahui bahwa masih terdapat beberapa aktivitas peneliti dalam melakukan kegiatan yang belum mencapai nilai Sangat Baik (SB). Adapun hambatan pada aktivitas tersebut adalah sebagai berikut: pertama, menjelaskan Nilai-nilai yang Terkandung dalam Permainan Tradisional Babintingan; kedua memberikan Contoh Cara Bermain Permainan Tradisional Babintingan; ketiga, memberikan Reward kepada Anak; dan keempat, melakukan Evaluasi

2) Observasi Aktivitas Anak

a) Mendengarkan Penjelasan guru.

b) Memperhatikan Guru

Ketika Memberikan Contoh Cara.

c) Melakukan Permainan tradisional Babintingan

d) Anak Menerima Reward

e) Selain itu, terdapat pula hambatan lainnya yaitu kurangnya kerjasama antara peneliti dan guru mengenai peran dalam penelitian, dan kerja sama antar pihak pihak yang bersangkutan seperti pihak dari SMP Bina Insan Mandiri dan penjaga sekolah.
2. Siklus 2

a. Perencanaan

Berdasarkan observasi dan refleksi dapat diketahui bahwa aktivitas peneliti dalam melakukan keempat aktivitas, belum semua mendapatkan skor sangat baik (SB). Adapun rencana perbaikan pada siklus I, adalah sebagai berikut:

1) Menjelaskan Nilai-nilai yang Terkandung dalam Permainan Tradisional Babintingan

2) Memberikan Contoh Cara Bermain Permainan Tradisional Babintingan

3) Pelaksanaan Tindakan Permainan Tradisional Babintingan

4) Memberikan Reward kepada Anak

5) Melakukan Evaluasi

Selain merubah teknik pelaksanaan tindakan sesuai masing- masing aktivitas, peneliti dan guru juga menjalin kerjasama kembali terkait dengan peran dalam penelitian dan berdiskusi tentang tema pembelajaran. Kemudian, peneliti membuat RPPH yang telah didiskusikan bersama guru kelas tentang kegiatan apa yang akan dilakukan. Selanjutnya, peneliti mempersiapkan media untuk menjelaskan tata cara bermain, posisi dan peran dalam permainan tradisional Babintingan, yaitu boneka wayang. Peneliti juga menyiapkan lembar instrumen perilaku prososial anak, lembar observasi aktivitas guru dan anak dengan menggunakan check list, serta kamera DSLR untuk mendokumentasikan proses kegiatan permainan tradisional Babintingan.

b. Pelaksanaan Tindakan

Pelaksanaan tindakan siklus II dilakukan selama dua kali pertemuan. Pelaksanaan tindakan siklus II pertemuan pertama dilakukan pada hari Selasa, 19 November 2019, pertemuan kedua pada hari Kamis, 21 November 2019. Kegiatan penelitian tetap dilakukan pada saat kegiatan pembuka, yaitu pada kegiatan motorik yang biasa dilakukan dikelas setelah berdoa.

c. Observasi

Hasil pengamatan perilaku prososial anak pada aspek empati siklus II diuraikan melalui tabel. 


\section{d. Refleksi}

Berdasarkan hasil observasi, maka didapatkan hasil bahwa terdapat peningkatan pada aktivitas anak dan guru. Terlihat pada aktivitas anak, anak sudah tertib pada saat mendengarkan guru ketika menjelaskan nilai-nilai yang terdapat dalam permainan tradisional Babintingan, memperhatikan guru ketika memberikan contoh permainan tradisional Babintingan dan mau mendengar serta menjawab pertanyaan dari guru ketika evaluasi. Selain itu, ketika melakukan permainan tradisional Babintingan anak terlihat sudah memahami dengan benar cara bermain yang telah dicontohkan oleh guru. Sedangkan, pada aktivitas guru dinilai sudah terdapat peningkatan, karena sudah mendapatkan skor sangat baik (SB) pada kelima aktivitas

Pada siklus II, hambatan-hambatan yang terjadi disiklus I sudah banyak berkurang. Tindakan yang peneliti lakukan pada siklus II terlihat lebih baik dibandingkan dengan tindakan siklus I, walau masih terdapat hambatan yaitu ketika permainan terhenti karena anak terjatuh dan terdapat anak yang tidak masuk, sehingga penilaian instrumen pada siklus II tidak maksimal. Tindakan pada siklus II telah mencapai indikator keberhasilan penelitian, sehingga peneliti menghentikan penelitian ini pada siklus II karena sudah mencapai indikator keberhasilan yang telah ditetapkan yaitu dengan nilai rata-rata ketercapaian dalam indikator.

Berdasarkan data yang diperoleh pada siklus II, dapat dikatakan bahwa tindakan yang dilakukan telah berhasil karena nilai yang diperoleh anak sudah melebihi target yang telah ditentukan pada indikator keberhasilan yaitu sebesar $75 \%$. Ketercapaian ini diperoleh karena dalam meningkatkan perilaku prososial anak usia 5-6 tahun dilakukan dengan kegiatan permainan tradisional Babintingan. Melalui permainan tradisional Babintingan dapat meningkatkan perilaku prososial anak baik dalam indikator empati, kepeduliaan dan kerja sama. Sebagaimana yang telah dijelaskan oleh Tim PlayPlus Indonesia dalam bukunya yaitu Ensiklopedia Permainan Tradisional Anak Indonesia (2016), melalui permainan tradisional Babintingan anak mendapakan banyak sekali nilai-nilai sosial yang tergabung dalam berbagai tindakan perilaku prososial. Adapun nilai-nilai dalam permainan, antara lain yaitu mempererat kekerabatan, mengajarkan perjuangan, melatih kesetiaan dan kerja sama tim, serta melatih tanggung jawab. Selain itu, karena menggunakan metode bermain permainan tradisional, maka terdapat hubungan aktif antar permainan dengan materi pembelajaran. Permendikbud RI Nomor 137 Tahun 2014 juga menjelaskan bahwa salah satu prinsip pembelajaran anak usia dini adalah belajar melalui bermain.

Kemudian, faktor lain yang mendukung meningkatnya perilaku prososial anak juga dikarenakan adanya reward yang diberikan, sehingga membuat anak menjadi semangat dan senang dalam mengikuti kegiatan permainan tradisional Babintingan. Faktor lain yang juga mendukung adalah indikator dari perilaku prososial anak disesuaikan dengan permasalahan yang ada di dalam kelas, yaitu empati, kepeduliaan dan kerja sama. Beaty dalam bukunya yang berjudul Observing Developement of The Young Child (Seventh Edition, 2013) menyatakan bahwa wilayah kedua dari perkembangan sosial anak usia dini adalah aspek positif perkembangan moral, yang lebih dikenal saat ini sebagai perilaku prososial. Wilayah ini mencakup perilaku seperti; empati, kemurahan hati, kepedulian dan kerja sama.

Apabila dikaitkan dengan aspek perkembangan lainnya, permainan tradisional Babintingan bukan hanya dapat mengembangkan dan melatih aspek perkembangan sosial dan emosional saja tetapi juga mempengaruhi aspek perkembangan lainnya seperti aspek perkembangan moral, fisik motorik, kognitif dan bahasa.

Pada aspek perkembangan moral, anak belajar untuk patuh pada peraturan yang telah ditetapkan dalam permainan. Pada aspek perkembangan fisik dan motorik, kemampuan motorik kasar terutama dalam berlari dapat berkembang dengan baik. Pada aspek perkembangan kognitif, ketika anak dapat mengatur strategi dalam permainan, pada saat itulah kemampuan anak dalam berpikir dapat meningkat. Selanjutnya pada perkembangan bahasa juga dapatberkembang dengan baik, yaitu ketika anak berdiskusi dengan teman satu timnya, serta setelah bermain anak diminta untuk mengkomunikasikan apa yang anak lakukan selama kegiatan bermain. 


\section{SIMPULAN DAN SARAN}

Berdasarkan hasil data yang diperoleh dapat disimpulkan bahwa terdapat peningkatan dalam perilaku prososial anak usia 5 - 6 tahun melalui permainan tradisional Babintingan di TK Bina Insan Mandiri. Aspek perilaku empati pada indikator mendengarkan orang lain mengalami peningkatan sebesar 64\%, anak yang sebelumnya tidak mendengarkan perintah guru mengalami perubahan pada siklus II sehingga dapat mendengarkan perintah dan koordinasi dari guru dan teman kelompoknya sendiri. Pada indikator menerima sudut pandang orang lain mengalami peningkatan sebesar $61 \%$, anak yang sebelumnya tidak menghargai temannya mengalami perubahan pada siklus II sehingga mmapu bersikap toleransi kepada seluruh temannya. Pada indikator peka terhadap orang lain mengalami peningkatan sebesar $64 \%$, anak yang sebelumnya tidak mau membantu teman mengalami perubahan pada siklus II sehingga dapat memberikan bantuan kepada seluruh temannya.

Aspek perilaku kepeduliaan dalam indikator melisankan dukungan mengalami peningkatan sebesar $68 \%$, anak yang sebelumnya masih melisankan kata negatif kepada temannya mengalami perubahan pada siklus II sehingga dapat melisankan kata positif kepada temannya. Pada indikator memberikan perlindungan fisik mengalami peningkatan sebesar $64 \%$, anak yang sebelumnya sengaja melukai temannya mengalami perubahan pada siklus II sehingga anak dapat melindungi temannya.

Aspek perilaku kerja sama dalam indikator bergiliran dalam beregiatan mengalami peningkatan sebesar 64\%, anak yang sebelumnya tidak mau bergantian dalam bermain mengalami perubahan pada siklus II sehingga mau bergantian tanpa perintah guru. Pada indikator memenuhi permintaan mengalami peningkatan sebesar $57 \%$, anak yang sebelumnya bersikap egois mengalami perubahan pada siklus II sehingga anak mampu memenuhi permintaan dari guru dan teman kelompoknya. Pada indikator mengoordinasikan segala tindakan mengalami peningkatan sebesar $82 \%$, anak yang sebelumnya bermain secara tidak teratur mengalami perubahan pada siklus II sehinnga anak mampu mengoordinasikan segala tindakan dirinya dan temannya dalam bermain tanpa bantuan guru.

Terjadinya peningkatan tersebut dikarenakan dalam meningkatkan perilaku prososial anak berupa aspek empati, kepedulian dan kerja sama dilakukan dengan melalui permainan tradisional Babintingan yang sebelumnya belum pernah diterapkan sebelumnya. Selain itu, dalam merencanakan penelitian, peneliti beracuan pada permasalahan prososial yaitu empati, kepedulian dan kerja sama yang terdapat di dalam kelas, seperti anak yang tidak melakukan apapun ketika temannya merasa sedih atau kesulitan, anak yang mengejek temannya ketika temannya dalam kesulitan, anak yang tidak mau bekerja sama ketika mengerjakan sesuatu yang bersifat kelompok, dan anak yang tidak mau meminjamkan barang- barang miliknya kepada temannya dengan menggunakan tehnik bermain permainan tradisional Babintingan seperti menjemput teman kelompoknya ketika ditawan oleh kelompok lawan, mengecohkan lawan ketika teman kelompok sedang terkepung, dan bekerja sama untuk menawan pemain lawan sebanyak- banyaknya dan merebut benteng lawan. Peningkatan juga terjadi karena adanya motivasi berupa reward yang membuat anak lebih semangat dalam melakukan permainan tradisional Babintingan.

Berdasarkan hasil penelitian tersebut, peneliti memberikan beberapa saran, diantaranya: Bagi Penyelenggara PAUD, khususnya taman kanak- kanak disarankan untuk terus meningkatkan dan mengembangkan metode yang tepat dan menarik sebagai upaya meningkatkan perilaku prososial anak. Bagi Masyarakat, sebaiknya masyarakat lebih mengenalkan permainan- permainan tradisional kepada anak terutama anak-anak di daerah perkotaan agar setiap anak mendapatkan kesempatan bermain permainan tradisional Indonesia juga dapat melestarikan budaya bangsa Indonesia.

Bagi guru hendaknya dalam pelaksanaan pembelajaran menggunakan berbagai metodemetode yang bervariasi seperti metode bermain permainan tradisional sehingga menyenangkan bagi anak-anak. Selain itu, guru juga diharapkan untuk melakukan beberapa kegiatan yang mendukung guna dapat mencapai tujuanpembelajaran dengan tepat seperti 
memberikan contoh secara langsung, menjelaskan dengan berbagai media yang bervariatif, melakukan kegiatan-kegiatan yang menyenangkan sebelum memulai pembelajaran, memberikan reward dan melakukan evaluasi dengan berbagai cara. Dan bagi kepala sekolah diharapkan dapat memberi masukan dan arahan kepada guru kelas agar memiliki kemampuan untuk menciptakan metode pembelajaran yang menarik untuk meningkatkan perilaku prososial anak, salah satunya melalui permainan tradisional Babintingan, bahkan dapat pula melalui permainan lain yang lebih inovatif tergantung dari kreativitas guru.

\section{DAFTAR PUSTAKA}

Astuti, P.P. (2012). Efektivitas metode bermain peran (role play) untuk meningkatkan kemampuan komunikasi pada anak. Skripsi. Yogyakarta. Universitas Ahmad Dahlan.

Beaty, J.J. (2013). Observing development of the young child (third edition). New Jersey: PrenticeHall Inc.

Desmita. (2009). Psikologi perkembangan peserta didik. Bandung: PT Remaja Rosdakarya.

Kusmaedi, N., dkk. (2010). Permainan tradisional. Bandung: Universitas Pendidikan Indonesia.

Papalia, D. E., Old, S. W., Feldman, R. D. (2009). Human development perkembangan manusia. Jakarta: Salemba Humanika.

Permendikbud RI No. 137 Tahun 2014 tentang standar nasional pendidikan anak usia dini. Jakarta.

Sugiono, U. (2014). Profil perilaku anak usia dini dan implikasinya terhadap program bimbingan pribadi sosial. Thesis. Bandung: Jurusan Bimbingan dan Konseling Universitas Pendidikan Indonesia.

Tim PlayPlus Indonesia. (2016). Ensiklopedia permainan tradisional anak indonesia. Jakarta: Erlangga. 